\title{
Radioimmunoassay for Estrone, Estradiol-17 $\beta$ and Estriol in Urine and Amniotic Fluid
}

\author{
Takuo MAKINO and Akira KAMBEGAWA \\ Pharmacological Research Department, Teikoku Hormone Mfg., Co. Ltd., \\ Shimosakunobe, Kawasaki, Japan \\ Tomoko KOKUBU \\ Clinical Laboratories, Teikoku Hormone Mfg., Go. Ltd.
}

Radioimmunoassay for estrone $\left(\mathrm{E}_{1}\right)$, estradiol- $17 \beta\left(\mathrm{E}_{2}\right)$ and estriol $\left(\mathrm{E}_{3}\right)$ in human urine and amniotic fluid is described. A sample volume of $0.002-4.0 \mathrm{ml}$ was used for the assay. As indicators, each tritiated estrogen of glucuronides, dominant conjugates in urine and amniotic fluid, was added to the samples to correct for procedural losses. Conjugated estrogens of glucuronide $(\mathrm{G})$ and sulfate(S) type were hydrolyzed with $15 \mathrm{vol} \% \mathrm{HCl}$ at $100^{\circ} \mathrm{G}$ for 60 minutes, and resulting free estrogens were extracted with ether. The dried extracts were applied to microcolumns of Sephadex LH-20, then $\mathrm{E}_{1}, \mathrm{E}_{2}$ and $\mathrm{E}_{3}$ were separated by eluting with benzene-methanol (85:15) mixture. A $1 / 2$ aliquot of the eluate was used for measuring recovery of the added tracer, and the remainder after being added with tritiated free estrogen was dried and incubated with the antiserum in a dilution of the borate buffer ( $\mathrm{pH}$ 8.0) containing $0.06 \%$ bovine serum albumin (BSA) and $0.05 \%$ bovine gamma globulin. The free and bound steroids were separated by $50 \%\left(\mathrm{NH}_{4}\right)_{2} \mathrm{SO}_{4}$, and tritium activities in the supernatant were counted. The antisera used for the assay were anti- $\mathrm{E}_{1}$ 17-BSA for $\mathrm{E}_{1}$, anti- $\mathrm{E}_{2}-6$-BSA for $\mathrm{E}_{2}$ and anti-E $\mathrm{E}_{3}-6$-BSA for $\mathrm{E}_{3}$, which had been prepared by us. In urine, all recoveries were $65.0 \pm 5.6$ (mean \pm S.D.) $\%$ for $\mathrm{E}_{1}-3-\mathrm{S}, 68.8 \pm$ $7.2 \%$ for $\mathrm{E}_{1}-3-\mathrm{G}, 64.5 \pm 5.8 \%$ for $\mathrm{E}_{2}-17 \beta-\mathrm{G}$ and $41.1 \pm 9.1 \%$ for $\mathrm{E}_{3}-16-\mathrm{G}$. In amniotic fluid, the recoveries were almost equal to those of the urine. Water blank in each estrogen assay was about $4 \mathrm{pg} /$ sample. Accuracy and precision of the method were satisfactory. The results determined by this radioimmunoassay were in good correlation with those determined by Brown's colorimetry at high estrogen concentration in urine. As this method is accurate and highly sensitive, we can determine estrogen values of low level or with small assay volume in both urine and amniotic fluid.

(See pp. 788〜796) 


\title{
Radioimmunoassay による尿および羊水中 estrogen の三分画測定法
}

\author{
帝国臟器製薬 薬理研究部 \\ 牧 野 拓 雄, 神戸川明 \\ 同臨床検查所
}

国 分 知 子

（昭和49年 1 月11日受付）

Radioimmunoassay (RIA) による尿および羊水中 estrogen の3 分画測定法を確立した。すすなわち， 被検物任回収率補正用の各 estrogen- ${ }^{3} \mathrm{H}$ glucuronide を添加してのち estrogen conjugates を酸水解し Sephadex LH-20 カラムクロマトにて estrone, estradiol-173, estriol に分画し，それぞれの抗 estrogen 血清を用いて RIA を行なつた，本法は従来の測定法に比較して迅速、簡便, 正確であり, きわめて感 度が高いととから，てれまで測定困難であつた少量の被検量や幼児，男子等 estrogen 含量の少ない尿 においても測定が可能である.

\section{I 緒 言}

一般に尿中 estrogen の測定は Kober 反応による比色法 ${ }^{122)}$, 螢光法 ${ }^{3)}$, ガスクロマトグラフイー法 ${ }^{4)}$ な゙ により行なわれているが, いずれも感度が低いため大量の被検尿を必要とし，尿中夾雑物の除去のために繁 雑な操作を行なわなければならず，羊水中 estrogen の測定も同様な問題点を有している.

近年，急速に進展した steroid の radioimmunoassay (RIA) ${ }^{5) 6}$ 亿より血中 estrogen (unconjugated) の 定量もルーチン測定が可能となりつつあるが，尿および羊水中 estrogen 定量についての報告は少なく，そ の測定法はいまだ確立していない.

われわれは estrogen に対する抗血清を作製し，RIA により血中 estrogen の測定法についてすでに報告 したが7)，今回は RIA による尿および羊水中 estrogen の測定法について基礎的検討を行ない，感度，精 度, 再現性ともに良好な free および conjugate 型 estrone $\left(E_{1}\right)$, estradiol-17 $\beta\left(E_{2}\right)$, estriol $\left(E_{3}\right)$ の 3 分 画測定法を確立したので報告する。

\section{II 実 験 材 料}

1) radioactive steroids

estrone-6, 7- ${ }^{3} \mathrm{H}\left(\mathrm{E}_{1}{ }^{-}{ }^{3} \mathrm{H}\right) \quad 40 \mathrm{Ci} / \mathrm{mM}$, estriol-6, $7-{ }^{3} \mathrm{H}\left(\mathrm{E}_{3}{ }^{3} \mathrm{H}\right) \quad 42.2 \mathrm{Ci} / \mathrm{mM}$, estrone-6, 7- ${ }^{3} \mathrm{H}-3 \beta$-D-glucuronide $\left(\mathrm{E}_{1}{ }^{3} \mathrm{H}-3 \mathrm{G}\right) 55 \mathrm{Ci} / \mathrm{mM}$, estrone-6, $7{ }^{-3} \mathrm{H}$-sulfate-ammonium salt $\left(\mathrm{E}_{1}{ }^{-3} \mathrm{H}-3 \mathrm{~S}\right) \quad 54.3 \mathrm{Ci} / \mathrm{mM}$, estradiol-6, 7- ${ }^{3} \mathrm{H}-17 \beta-\mathrm{D}$-glucuronide ( $\left.\mathrm{E}_{2}{ }^{3} \mathrm{H}-17 \mathrm{G}\right)$ はいずれも New England Nuclear 社製, estradiol-6, 7- ${ }^{3} \mathrm{H}\left(\mathrm{E}_{2}{ }^{-3} \mathrm{H}\right)$ 40Ci $/ \mathrm{mM}$ は The Radiochemical Centre 社製で, すべて Sephadex LH-20 カラムクロマトにより精製後 使用する.すなわち，free estrogen- ${ }^{3} \mathrm{H}$ においては benzene : methanol (85:15) により各ステロイドの 溶出部位を採取し, conjugate estrogen- ${ }^{3} \mathrm{H}$ においては methanol $0.1 \mathrm{ml}$ にて 2 回カラムに添加後 benzene : methanol (85:15) 8ml にて prewash を行ない, ついで benzene : methanol (50:50) 5ml の溶出部 
位を採取する。

2) $\mathrm{E}_{3}-16-\mathrm{G}:$ 帝国臓器製薬

3）抗血清 : 用いた抗 estrogen 血清の特性および本抗血清を用いて作製した標準曲線については既報?) の通りである.なお, Abraham ${ }^{8)}$ の方法および scatchard plot $^{9)}$ により求めた association constant $(\mathrm{K})$ は抗 $\mathrm{E}_{1}$ 血清 $1.83 \times 10^{10} \mathrm{l} / \mathrm{mole}$, 抗 $\mathrm{E}_{2}$ 血清 $5.03 \times 10^{9} l / \mathrm{mole}$, 抗 $\mathrm{E}_{3}$ 血清 $5.78 \times 10^{9} l / \mathrm{mole}$ であつた。

4 ) 試薬類, クロマトカラム, 抗血清稀釈液, ジオキサンシンチレーターなどの調製法も既報〕にしたが う.

\section{III 測 定 方 法}

\section{1) 測定試料}

測定に用いる尿量あるいは羊水量は，その中に含まれているステロイド量が assay 時に 20〜500pg の範 因内になるように設定し，被検量が $0.1 \mathrm{ml}$ 以下で測定を行なう場合は水で稀釈して $0.1 \mathrm{ml}$ とする。なお Table 1 は測定に用いるおよその被検量である.

Table 1. Approximate urine and amniotic fluid volume ( $\mathrm{ml}$ ) used for the assay of free and conjugate estrogens

\begin{tabular}{l|c|c}
\hline & free & conjugate \\
\hline \hline (URINE) & $0.5 \sim 2.0$ & $0.2 \sim 1.0$ \\
child & $0.2 \sim 0.5$ & $0.05 \sim 0.1$ \\
male & & \\
female & $0.1 \sim 0.2$ & $0.05 \sim 0.1$ \\
follicular & $0.1 \sim 0.2$ & $0.01 \sim 0.05$ \\
ovulatory & $0.1 \sim 0.2$ & $0.01 \sim 0.05$ \\
luteal & $0.05 \sim 0.1$ & $0.001 \sim 0.005$ \\
pregnant 6 10W & & $0.02 \sim 0.05$ \\
\hline (AMNIOTIG FLUID) & $0.05 \sim 0.1$ & $0.001 \sim 0.005$ \\
pregnant 20 35W & $0.005 \sim 0.01$ & \\
$\quad 36 \sim 40 \mathrm{~W}$ &
\end{tabular}

\section{2 ）酸加水分解および分離精製}

測定試料に $\mathrm{E}_{1}, \mathrm{E}_{2}, \mathrm{E}_{3}$ の各 glucuronide 型 ${ }^{3} \mathrm{H}$ 標識物の各 $1000 \mathrm{dpm}$ を含む水溶液を添加し，さらに 稀塩酸（濃塩酸 $26 \mathrm{ml}$ 水で $100 \mathrm{ml}$ としたもの）を水首と等量加えて $100^{\circ} \mathrm{C}, 60$ 分間加熱する. のち水冷して これに10倍量のエーテルを加えて thèrmo-mixer そて振䔽後，下層を吸い上げて捨て，ついでエーテル層 を水洗後, 上清を他の試験管に移してわずかに加温しつつ窒素ガススプレーにより乾固する，てれを Sephadex LH-20 のミクロカラムに benzene : methanol (85:15) 0.1ml で 2 回添加し, さらに同じ溶媒を流 して estrogen の各溶出 fraction を採取する。通常, 内径 $7 \mathrm{~mm}$ のカラムに LH-20 $2 \mathrm{ml}$ 允てんした場 合には $\mathrm{E}_{1}$ は 1.8〜2.4ml, $\mathrm{E}_{2}$ は 3.0〜 4.2 $\mathrm{ml}, \mathrm{E}_{3}$ は5.4〜 7.4 $\mathrm{ml}$ に溶出し，再現性はきわめて良好である. ての溶出液の $1 / 2$ 量は回収率を補正するためにシンチレーターを加えて液体シンチレーションカウンターに て放射能量を測定し，残りについて RIA を行なう。

\section{3) RIA}

残りの1/2量の $\mathrm{E}_{1}, \mathrm{E}_{2}, \mathrm{E}_{3}$ 各 fraction そその ${ }^{3} \mathrm{H}$ 標識 estrogen 10,000dpm を加えて乾固し, $\mathrm{E}_{1}, \mathrm{E}_{2}, \mathrm{E}_{3}$ の稀橎抗血清 $0.25 \mathrm{ml}$ をれぞれに加えて室温で10分間放置し， $50 \%\left(\mathrm{NH}_{4}\right)_{2} \mathrm{SO}_{4} 0.25 \mathrm{ml}$ を加えて10分後に 
遠沈して上清 $0.2 \mathrm{ml}$ c counting vial に入れ, dioxane scintillator $12 \mathrm{ml}$ を加えて放射能を測定する.

なお，検体と同時に各 estrogen の 0,20,50,100, 200,500pg およびその estrogen- ${ }^{3} \mathrm{H}$ 10,000dpm を 用いて同様に RIA を行ない $\mathrm{E}_{1}, \mathrm{E}_{2}, \mathrm{E}_{3}$ の標準曲線を作製する. そして, この標準曲線を用いて検体の放 射能測定值からその含有 estrogen 量を求める.

4 ) 測定試料中 estrogen 濃度 (s) の算出

$$
\begin{aligned}
& \mathrm{S}(\mathrm{ng} / \mathrm{ml})=(\mathrm{M}-\mathrm{a}) \times \frac{100}{\text { 回収率 }(\%)} \times \frac{2}{\text { 被検尿量 }} \times \frac{1}{10^{3}} \\
& \mathrm{M}: \text { 標準曲線から求めた estrogen 量 } \\
& \mathrm{a}: \text { water blank } \\
& \text { 回収率 }: \text { 測定試料中に加えた放射能量を Ro, クロマト溶出液の } 1 / 2 \text { 量の放射能量を } \mathrm{R} \text { とすと } \\
& \quad \frac{2 \mathrm{R}}{\mathrm{R}_{0}} \times 100 \text { により求まる. }
\end{aligned}
$$

\section{5 ) Free 型と Conjugate 型の分画测定}

尿および羊水中の free 型と conjugate 型 estrogen を分画して測定する場合には，まず測定試料に free 型 estrogen- ${ }^{3} \mathrm{H}$ 各 $1000 \mathrm{dpm}$ を加えてエーテル抽出し，てれを free fraction とする. 残りの水層には estrogen- ${ }^{3} \mathrm{H}$ glucuronide 各 $1000 \mathrm{dpm}$ を加えて加水分解後, エーテル抽出し conjugate fraction とする. 両方の fraction は以後, 同様の操作を行なつて estrogen 量を測定する.

\section{IV 実 験 成 績}

\section{1 加水分解}

結合型 estrogen の加水分解についてはすでにわれわれも詳細な検討を行なつているが゙2，本実験におい ては immunoassay level での被検量における酸水解の影響について検討した. すなおち，5倍稀釈の男子 尿 $0.1 \mathrm{ml}$ に $\mathrm{E}_{1}{ }^{-}{ }^{3} \mathrm{H}-3 \mathrm{~S}, \mathrm{E}_{1}{ }^{3} \mathrm{H}-3 \mathrm{G}, \mathrm{E}_{2}{ }^{3} \mathrm{H}-17 \mathrm{G}, \mathrm{E}_{3}-16 \mathrm{G}$ の $30 \sim 500 \mathrm{pg}$ を加えて $15 \mathrm{vol} \% \mathrm{HCl}, 100^{\circ} \mathrm{C}$ に おいて水解後, 既述の方法により抽出, クロマトを行なつて各 estrogen fraction をとり, ${ }^{3} \mathrm{H}$ 標識物につ いては放射能量を測定， $\mathrm{E}_{3}-16 \mathrm{G}$ については RIA により $\mathrm{E}_{3}$ 量を測定して estrogen conjugates の酸水解 される割合を検討した。

この結果は Fig. 1 亿示すごとくで， $\mathrm{E}_{1}-3 \mathrm{~S}$ はほぼ10分位で maximumに達するのに反し，一般に glucuronides は60分程度の水解時間が必要であつた. しかし，それ以上の加熱ではむしろ回収される estrogen は低值となるととからも水解時間は60分が適当と思われる.

\section{2 尿不純物の除去}

本実験に用いた $\mathrm{E}_{2}$ および $\mathrm{E}_{3}$ 抗血清の高い特異性を利用し，クロマトを省略して $\mathrm{E}_{2}$ および $\mathrm{E}_{3}$ を測定する 方法が妊婦血漿において可能であるが ${ }^{10)}$ ，尿および羊水中 $\mathrm{E}_{3}$ について検討した結果ではクロマトによる分 離精製を省略するとクロマトをした場合よりもはるかに高值を示す (Table 2).

これは尿および羊水中不純物の影響であり，LH-20 カラムクロマトにおいては，乙れら不純物は void volume のすぐあとに溶出し，除去が可能であつた，尿において数被検量が $2 \mathrm{ml}$ を越えると尿中不純物の 一部は $\mathrm{E}_{1}$ fraction に混入し測定值に影響を及ぼすが，幼児においても被検尿量は $1 \mathrm{ml}$ 以下で十分測定可 能であるととから，ほとんどすべての検体において，てのクロマトにより尿中ブランクの除去は可能であろ う.

\section{3 回収率}

Estrogen conjugates の本測定における回収率を酸水解時, 酸水解後, 全行程について検討した. すなわ ち $\mathrm{E}_{1-}{ }^{3} \mathrm{H}-3 \mathrm{~S}, \mathrm{E}_{1-}{ }^{3} \mathrm{H}-3 \mathrm{G}, \mathrm{E}_{2}{ }^{3} \mathrm{H}-17 \mathrm{G}$ および $\mathrm{E}_{3}-16 \mathrm{G}$ を男子尿 $0.1 \mathrm{ml}$ および妊娠 3 力月の羊水 $0.005 \mathrm{ml}$ 亿加 えて全行程の回収率を求め, さらに, 酸水解後にそれぞれの free estrogen- ${ }^{3} \mathrm{H}$ を加えて水解後の回収率を 求め, 両者の差から水解時における回収率を求めた. 
Fig. 1. Effect of $\mathrm{HCl}$ hydrolysis time to estrogen conjugate added to urine (Hydrolysis : HGl 15 vol\% at $100^{\circ} \mathrm{C}$ )

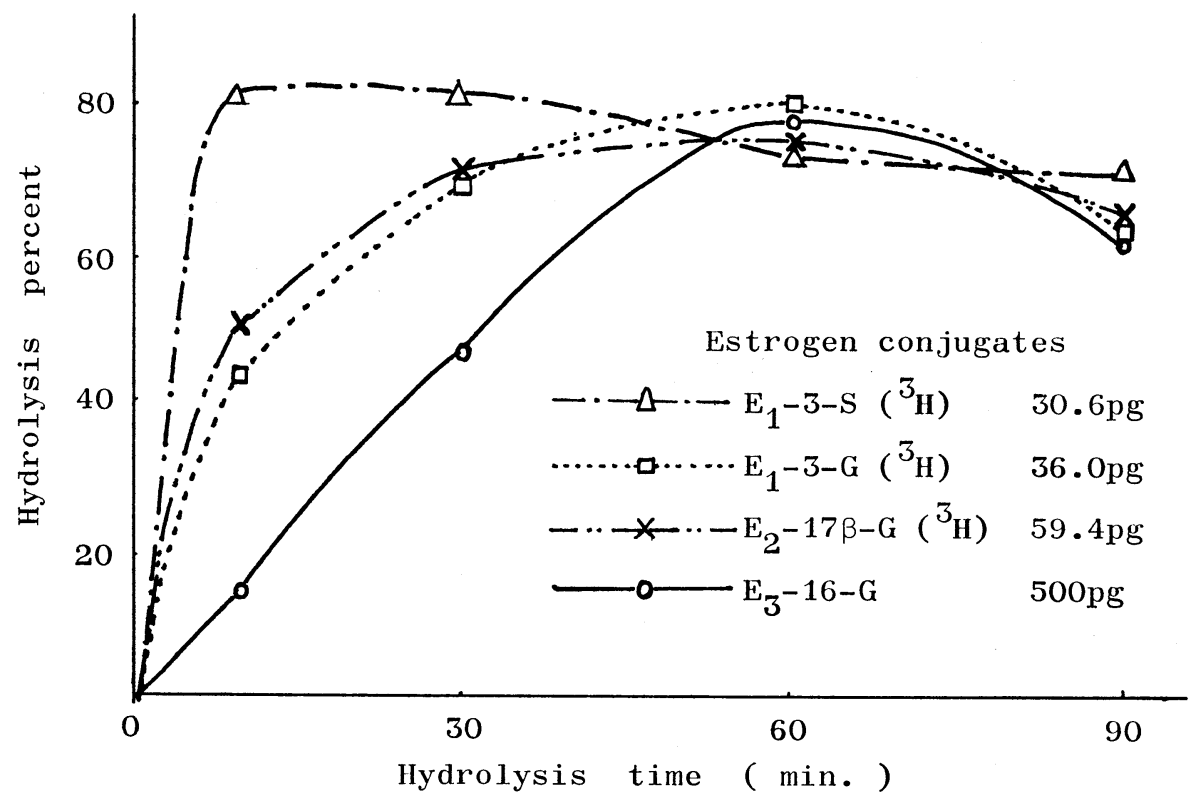

Table 2. Comparison of urine and amniotic fluid estriol values ( $\mathrm{ng} / \mathrm{ml}$ ) between with and without chromatography

\begin{tabular}{c|r|r|r|r}
\hline \multirow{2}{*}{} & \multirow{2}{*}{ case } & \multicolumn{2}{|c|}{ chromatography } & \multirow{2}{*}{ ratio } \\
\cline { 3 - 5 } & & without & with & \\
\hline \hline \multirow{2}{*}{ URINE } & 1 & 2.96 & 0.81 & 3.65 \\
& 2 & 10.9 & 3.27 & 3.33 \\
& 3 & 18.1 & 7.74 & 2.34 \\
& 4 & 20.9 & 13.4 & 1.57 \\
& 5 & 22.3 & 9.51 & 2.34 \\
& 6 & 36.8 & 15.2 & 2.45 \\
& 7 & 106.5 & 62.7 & 1.70 \\
& 8 & 224.3 & 96.1 & 2.33 \\
\hline \multirow{2}{*}{ AMNIOTIC FLUID } & 1 & 110.5 & 89.5 & 1.23 \\
& 2 & 267.4 & 106.9 & 2.50 \\
& 3 & 385.0 & 243.8 & 1.58 \\
\hline
\end{tabular}

この結果は Table 3 亿示すでとくで尿および羊水ともに酸水解後には $\mathrm{E}_{1} ， \mathrm{E}_{2}$ では約 70〜80\%， $\mathrm{E}_{3}$ で は約50\%の回収率であり，全行程における回収率は $\mathrm{E}_{1} ， \mathrm{E}_{2}$ では 60〜70\%， $\mathrm{E}_{3}$ では約40\%であつた。 した がつて酸水解時における loss はいずれも20\%前後である.

\section{4 精度および再現性}

男子尿 $0.02 \mathrm{ml}$ および妊娠 3 カ月の羊水 $0.005 \mathrm{ml}$ 中に estrogen conjugates の一定量を加えて全測定操作 を行ない回収率を補正して検討した本測定法の accuracy は Table 4 に示すでとくほぼ満足すべきもので 
Table 3. Percent recovery of labelled and non-labelled estrogen conjugates added to urine and amniotic fluid (mean \pm S.D.)

\begin{tabular}{l|r|r|r|r}
\hline \multicolumn{1}{c|}{ added conjugate } & $\mathrm{E}_{1}-3-\mathrm{S}\left({ }^{3} \mathrm{H}\right)$ & $\mathrm{E}_{1}-3-\mathrm{G}\left({ }^{3} \mathrm{H}\right)$ & $\mathrm{E}_{2}-17 \beta-\mathrm{G}\left({ }^{3} \mathrm{H}\right)$ & $\mathrm{E}_{3}-16-\mathrm{G}$ \\
\hline \hline (URINE) & & & & \\
during hydrolysis & $78.7 \pm 6.8$ & $83.3 \pm 8.8$ & $79.4 \pm 7.2$ & $80.4 \pm 9.1$ \\
after hydrolysis & $82.6 \pm 5.6$ & $82.6 \pm 5.6$ & $81.2 \pm 8.5$ & $49.8 \pm 7.3$ \\
over all recovery & $65.0 \pm 5.6$ & $68.8 \pm 7.2$ & $64.5 \pm 5.8$ & $41.1 \pm 9.1$ \\
\hline (AMNIOTIG FLUID) & & & & \\
during hydrolysis & $77.7 \pm 9.8$ & $81.0 \pm 8.5$ & $87.5 \pm 7.5$ & $80.4 \pm 8.9$ \\
after hydrolysis & $78.9 \pm 5.4$ & $78.9 \pm 5.4$ & $70.3 \pm 5.5$ & $49.1 \pm 6.3$ \\
over all recovery & $61.3 \pm 6.0$ & $63.9 \pm 6.5$ & $61.5 \pm 7.2$ & $39.5 \pm 7.7$ \\
\hline
\end{tabular}

Table 4. Recovery of estrogen conjugate added to $0.02 \mathrm{ml}$ of male urine and $0.005 \mathrm{ml}$ of amniotic fluid

\begin{tabular}{|c|c|c|c|c|c|c|}
\hline \multirow{2}{*}{ added conjugate } & \multirow{2}{*}{$\begin{array}{l}\text { added } \\
\mathrm{pg} \text { as } \\
\text { free }\end{array}$} & \multicolumn{4}{|c|}{ steroid quantified as free } & \multirow{2}{*}{$\begin{array}{l}\text { regression } \\
\text { equation }\end{array}$} \\
\hline & & $\begin{array}{c}\operatorname{mean} \\
(\mathrm{pg})\end{array}$ & $\begin{array}{c}\text { standard } \\
\text { deviation }\end{array}$ & $\begin{array}{l}\text { standard } \\
\text { error }\end{array}$ & $\begin{array}{l}\text { coefficient of } \\
\text { variation }(\%)\end{array}$ & \\
\hline \multicolumn{7}{|l|}{ (URINE) } \\
\hline \multirow{4}{*}{$\mathrm{E}_{1}-3-\mathrm{S}$} & 0 & 40.1 & 3.97 & 2.29 & 9.90 & \multirow{4}{*}{$Y=1.05 X+34.1$} \\
\hline & 50 & 83.8 & 5.65 & 3.26 & 6.73 & \\
\hline & 200 & 231 & 17.7 & 10.2 & 7.63 & \\
\hline & 500 & 550 & 88.1 & 50.9 & 16.1 & \\
\hline \multirow{4}{*}{$\mathrm{E}_{2}-17 \beta-\mathrm{G}$} & 0 & 16.7 & 3.50 & 2.02 & 20.9 & \multirow{4}{*}{$Y=0.88 X+16.6$} \\
\hline & 50 & 49.0 & 8.55 & 4.94 & 17.4 & \\
\hline & 200 & 208 & 9.46 & 5.46 & 4.52 & \\
\hline & 500 & 450 & 34.1 & 19.7 & 7.58 & \\
\hline \multirow{6}{*}{$\mathrm{E}_{3}-16-\mathrm{G}$} & 0 & 130 & 23.7 & 13.7 & 18.2 & \multirow{6}{*}{$Y=0.95 X+134$} \\
\hline & 25 & 158 & 28.6 & 16.5 & 18.1 & \\
\hline & 50 & 173 & 24.6 & 14.2 & 14.2 & \\
\hline & 100 & 238 & 27.1 & 15.6 & 11.3 & \\
\hline & 200 & 330 & 27.7 & 16.0 & 8.39 & \\
\hline & 500 & 606 & - 39.4 & 22.7 & 6.49 & \\
\hline (AMNIOTIG FLUID) & & & & & & \multirow{5}{*}{$Y=0.87 X+20.4$} \\
\hline \multirow{4}{*}{$E_{1}-3-S$} & 0 & 19.0 & 5.60 & 2.32 & 29.5 & \\
\hline & 50 & 60.2 & 2.86 & 1.64 & 4.75 & \\
\hline & 200 & 196 & 18.9 & 10.9 & 9.65 & \\
\hline & 500 & 457 & 43.2 & 24.9 & 9.44 & \\
\hline \multirow{3}{*}{$\mathrm{E}_{3}-16-\mathrm{G}$} & 0 & 21.8 & 2.62 & 1.52 & 10.4 & \multirow{3}{*}{$Y=0.91 X+28.6$} \\
\hline & 200 & 219 & 13.5 & 7.77 & 6.17 & \\
\hline & 500 & 482 & 71.0 & 41.0 & 14.7 & \\
\hline
\end{tabular}

No. of determinations : $3 \sim 4$

$\mathrm{X}=$ steroid added, $\mathrm{Y}=$ steroid quantified 
あつた。 また，尿中 $\mathrm{E}_{3}$ を duplicate で測定して求めた precision は within (intra-) assay variance が

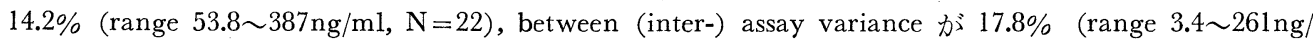
$\mathrm{ml}, \mathrm{N}=10$ ) であり，男子尿中 $\mathrm{E}_{3}$ を 5 回反復測定して求めた reproducibility は $6.69 \pm 0.932 \mathrm{ng} / \mathrm{ml}$ (mean \pm S.D.), C.V. (coefficient of variance) $13.9 \%$ であつた.

\section{Water blank}

水を用いて全測定操作を行なつて求めた water blank 值は free と conjugate との間に差はなく， $\mathrm{E}_{1}$ $4.40 \pm 2.87 \mathrm{pg}, \mathrm{E}_{2} 4.13 \pm 3.18 \mathrm{pg}, \mathrm{E}_{3} 4.10 \pm 4.07 \mathrm{pg}$ (いずれも $\mathrm{N}=20$ ) であつた.

\section{Brown-神戸川変法と本法との比較}

従来，われわれが尿中 estrogen のルーチン検査に用いている Brown-神戸川変法と本法との相関関係は 同一尿について $\mathrm{E}_{1}, \mathrm{E}_{2}, \mathrm{E}_{3}$ 值を両者の測定法で比較したとてろ Fig. 2 亿示すでとく有意の相関か認められ

Fig. 2. Comparison of urinary estrogen values between colorimetry by Brown-Kambegawa's and radioimmunoassay by our method

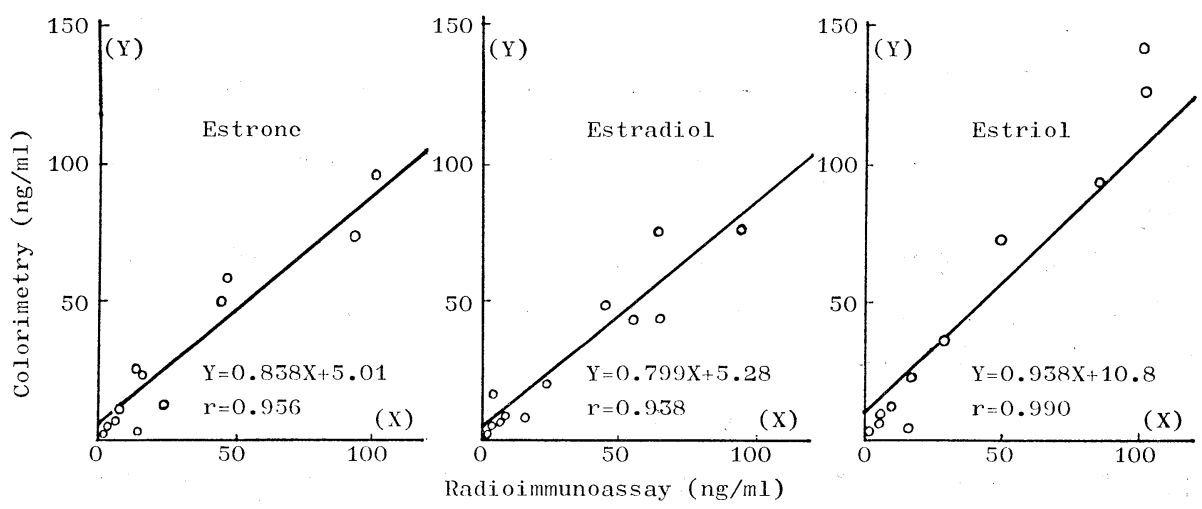

た（ $\mathrm{P}<0.01 ）$ 。しかし，およそ $5 \mathrm{ng} / \mathrm{ml}$ 以下の低 estrogen 濃度においては両者の測定值間に差が認めら れた.

\section{7 測定值}

本法による正常有経婦人および妊娠初期婦人における尿中 free および conjugate estrogen 值を Table 5

Table 5. Urinary free $(F)$ and conjugate $(C)$ estrogen levels of normal and early pregnant females determined by radioimmunoassay

\begin{tabular}{l|c|c|c|c}
\hline & & estrone & estradiol & estriol \\
\hline Follicular (4) & F & $0.09 \pm 0.06$ & $0.22 \pm 0.08$ & $0.29 \pm 0.33$ \\
& G & $0.65 \pm 1.05$ & $1.94 \pm 0.67$ & $3.00 \pm 1.85$ \\
\hline \multirow{2}{*}{ Ovulatory (4) } & F & $0.13 \pm 0.18$ & $0.12 \pm 0.17$ & $0.38 \pm 0.18$ \\
& $\mathrm{G}$ & $7.70 \pm 4.61$ & $4.83 \pm 1.02$ & $10.6 \pm 4.63$ \\
\hline \multirow{2}{*}{ Luteal (5) } & $\mathrm{F}$ & $0.43 \pm 0.44$ & $0.08 \pm 0.09$ & $0.26 \pm 0.17$ \\
& $\mathrm{G}$ & $4.54 \pm 0.85$ & $3.67 \pm 0.87$ & $5.27 \pm 0.97$ \\
\hline Pregnancy (4) & $\mathrm{F}$ & $4.47 \pm 5.07$ & $5.09 \pm 2.87$ & $3.75 \pm 2.73$ \\
7〜9 week (4) & $\mathrm{G}$ & $51.8 \pm 37.7$ & $22.4 \pm 2.82$ & $89.5 \pm 49.5$ \\
\hline
\end{tabular}

values $: \mathrm{ng} / \mathrm{ml}$ (mean \pm S.D.).

parentheses : No. of determinations 
Table 6. Urinary estrogen values $(\mathrm{ng} / \mathrm{ml})$ determined by radioimmunoassay

\begin{tabular}{l|c|c|c|c}
\hline name (age) & case & estrone & estradiol & estriol \\
\hline \hline T.H. (75) & postmenopausal & 0.41 & 0.47 & 1.28 \\
T.S. (50) & " & 0.45 & 0.51 & 0.56 \\
T.M. (36) & male & 1.76 & 1.63 & 6.65 \\
S.S. (26) & " & 0.20 & 0.09 & 3.36 \\
M.K. ( 4) & " & 0.11 & 0.66 & 0.37 \\
H.A. ( 4) & prematurity & 0.13 & 1.07 & 0.81 \\
M.T. ( 5) & " & 0.80 & 1.37 & 1.22 \\
K.M. (4) & " & 0.52 & 0.62 & 3.19 \\
S.H. (0) & 4 days after birth & & & 46.0 \\
K.M. (0) & 5 days after birth & & & 43.4 \\
H.T. ( 0) & " & & & 26.6 \\
A.E. (0) & " & & & 65.6 \\
\hline
\end{tabular}

に, また, 従来測定困難であつた男子, 更年期婦人, 小児 (性早熟症), 新生児の尿中 estrogen 值を Table 6 亿示す.

一方, 妊娠10力月の羊水中 estrogen 值 $(\mathrm{N}=8)$ は $\mathrm{E}_{1} 25.1 \pm 11.3, \mathrm{E}_{2} 17.3 \pm 7.40, \mathrm{E}_{3} 232 \pm 84.0(\mathrm{ng} / \mathrm{ml}$, mean \pm S.D.) であつた. なお, free estrogen の割合は $\mathrm{E}_{3}$ においては $3.27 \pm 1.48 \%$ であり，ほとんどが conjugates として存在していた.

\section{$\mathrm{V}$ 考 察}

尿中に排泄される estrogen の存在様式については Neeman ら ${ }^{11) 12}$ が妊婦尿から $\mathrm{E}_{3}-16-\mathrm{G}$ を同定しての ち，とくに Diczfalusy 一派 ${ }^{13) 14}$ により $\mathrm{E}_{3}-3-\mathrm{G}, \mathrm{E}_{3}-3-\mathrm{S}$ 等の尿中 $\mathrm{E}_{3}$ 代謝物が同定されている. その後, さ らに conjugated estrogen として $\mathrm{E}_{1}-3-\mathrm{G}, 16 \alpha-\mathrm{OH}-\mathrm{E}_{1}-3-\mathrm{S}-16 \alpha-\mathrm{G}, 16 \alpha-\mathrm{OH}-\mathrm{E}_{1}-3-\mathrm{G}, 16 \alpha \mathrm{OH}-\mathrm{E}_{1}-16 \alpha-\mathrm{G}, \mathrm{E}_{2}-$ $17 \beta-\mathrm{G}$, epi- $\mathrm{E}_{3}-16 \beta-\mathrm{G}, \mathrm{E}_{3}-3-\mathrm{S}-16 \alpha-\mathrm{G}$ 等の存在が認められ ${ }^{15)}$, 妊娠末期において尿中 estrogen の大部分をし める $\mathrm{E}_{3}$ conjugates の排泄は $\mathrm{E}_{3}-16-\mathrm{G} 68.0 \%, \mathrm{E}_{3}-3-\mathrm{G} 22.9 \%, \mathrm{E}_{3}-3-\mathrm{S}-16-\mathrm{G} 6.5 \%, \mathrm{E}_{3}-3-\mathrm{S}$ 2.5\% であると報 告されている ${ }^{16)}$.

しかし，非妊婦人や男子においては estrogen の排泄量がわずかであるということもあつてその尿中代謝 物および抱合型についてはほとんど検討されていない.

われわれの作製した抗 estrogen 血清は free 型 estrogen と反応し, conjugate 型とは一部を除いてほと んど affinity をもたない. したがつて本抗血清を用いて尿中 estrogen を測定するためには estrogen conjugates の加水分解を行なう必要がある.

尿中 estrogen の測定をルーチンに行なうには尿中に多種にわたつて存在する各種 estrogen を測定する ことは困難であるため, 加水分解後代表的 estrogen である $\mathrm{E}_{1}, \mathrm{E}_{2}, \mathrm{E}_{3}$ の測定を行なつた. 加水分解に は各種の方法があるが，簡便で迅速であるとと，glucuronide と sulfate がともに水解出来るととなどから 酸水解法を採用した。しかし，一般に estrogen は酸加熱により酸化的に分解されることが知られており， れわれも borate buffer および精製水へ $\mathrm{E}_{3}-16-\mathrm{G}$ および $\mathrm{E}_{3}$ を添加して既述の条件で酸水解を行なうと free $\mathrm{E}_{3}$ としての回収は $\mathrm{E}_{3}-16-\mathrm{G}$ では添加量の 30〜40\%， $\mathrm{E}_{3}$ では 10\% 以下であつた. このととはbuffer 中および精製水中では $\mathrm{E}_{3}$ が酸加熱により分解するものと思われる。 一方, 尿中へ $\mathrm{E}_{3}-16-\mathrm{G}$ および free $\mathrm{E}_{3}$ を添加して酸加熱を行なっても， $\mathrm{E}_{3}$ の分解は60分以内ではほとんどみられなかつた. とのととは尿中 不純物か酸加熱による $\mathrm{E}_{3}$ の分解を防禦しているのであろう.

測定時の回収率補正は尿中に存在する $\mathrm{E}_{1}, \mathrm{E}_{2}, \mathrm{E}_{3}$ の各種抱合型のすべてについて行なうことは実際上， 
困難であり，しかも入手可能である high specific な conjugate 型 estrogen ${ }^{3} \mathrm{H}$ の種類にも限りがある. 加えるに，妊娠時を除いては尿中 estrogen 抱合型の種類およびその割合がいまだ明らかでないてとを考元 ると，尿中には glucuronide 型が大半をしめると思われるので，入手可能な estrogen- ${ }^{3} \mathrm{H}$-glucuronide を 代表させて回収率補正を行なうこともやむを得ないものと考える。ささらに測定手技が一定したのちは酸水 解後に free estrogen- ${ }^{3} \mathrm{H}$ を加えて水解後の操作における回収率を求め, それに水解時における estrogen conjugates の平均回収率を $82.0 \%$ として，0.82倍した值を全測定操作における回収率とするととも可能で ある.

本測定法においては被検尿量がきわめてわずかであるために，一日全尿を蓄尿して一日排泄量を求める場 合には被榆尿の採取量誤差に留意する必要がある，ての点から，尿中 estrogen 濃度の高い妊婦尿において は比較的精度よく測定出来る比色法 ${ }^{2171}$ によるのが賢明であろう。

Estrogen conjugates の RIA には，それと親和性をもつ抗血清を用いて測定すれば加水分解は不要であ る. Gurpide 弓 ${ }^{18)}$ は $\mathrm{E}_{3}$-16, 17-dihemisuccinyl-BSA による抗血清を用いて妊婦尿を直接反応させるとと により尿中 estrogen の測定を行なつている。しかし， $\mathrm{E}_{3}-16 \mathrm{G}, \mathrm{E}_{1}, \mathrm{E}_{2}, \mathrm{E}_{2}-17 \mathrm{G}, 16-\mathrm{keto}-\mathrm{E}_{2}$ などはこの抗 血清に対し $\mathrm{E}_{3}$ と同程度の affinity を有するが, sulfate 型や 3-glucuronide 型の estrogen は affinity を 持たないため測定值は尿中 total estrogen 值を示すととにはならず，乙の抗血清に対する 'immunoreactive' estrogen 值を示すてとになる，娃娠時には $E_{3}-16 G$ が尿中 estrogen の大半を占めるので，ての方法は簡 易測定法として価值があるが，てれによる criteria を確立するためには測定はすべて同一抗血清による必要 があろう. Castanier $~^{199}$ は尿を水解後，直接 $\mathrm{E}_{2}-17 \beta$-succinyl-BSA 抗血清を反応させているが，乙の抗血 清も各種 estrogens に対して affinity を有するため, 測定值は ' $\mathrm{E}_{2}$ equivalent' あるいは 'estrogens as $\mathrm{E}_{2}$ ' として示される.

われわれは，水解後クロマトにより $\mathrm{E}_{1}, \mathrm{E}_{2}, \mathrm{E}_{3}$ を分離して RIA を行なつたが，ての方法は直接抗血清 そ反応させる方法に比較して煩雑であるのは否めない，しかし， $\mathrm{E}_{1}, \mathrm{E}_{2}, \mathrm{E}_{3}$ そのものを測定しているという 価値はあるものと思われる。

free steroid に対する抗血清作製の報告は数多くあるが， conjugate steroid に対するそれの報告はほとん ぞなくわずかに testosterone glucuronide 抗血清による尿中 testosterone の測定 ${ }^{20)}$ と estrogen を含む各 種 steroid glucuronide BSA 亿対する抗血清の作製 ${ }^{21}$ が散見されるにすぎない

しかし, estrogen においてはその抱合型の種類も多く, しかもてれら抱合型の分離操作は煩雑である ため ${ }^{22)}$ ，きわめて特異性の高い抗血清を除いて，直接測定の際には何を測定しているのかが問題となろう。

羊水中 estrogen の大部分は $\mathrm{E}_{3}$ およびその抱合体であり ${ }^{23) 24)}$ ，その大半は glucosiduronate が占め sulphate がてれにつぎ free はわずかであるとされている ${ }^{25)}$. 従来の方法で羊水中 estrogen を測定するには妊 娠末期においても羊水 $10 \mathrm{ml}$ 程度を必要とするが RIA におては感度が優れているため，0.1 $\mathrm{ml}$ 以下で十分で あり，その測定法は尿と全く同様に行なうことができた，今後，羊水中ステロイド分析の進展により，母胎児一胎盤系の内分泌相関が一首明らがなるであろう。

今後は尿中，羊水中のみならず，血中においても dominant estrogen である conjugate 型の測定が進展 し，そのルーチン化と測定値に関する criteria の確立が期待される.

稿を終わるにあたり，御校閲を睗わつた帝国臟器製薬薬理研究部長鈴木竜太博士に感謝致します。また， 羊水の测定に際し多大の御示唆と羊水の御提供を頂きました広島大学医学部産婦人科藤原篤教授ならびに同 教室笹木智子先生に深謝致します.

なお, 本論文の要旨は第21回日本内分泌学会東部部会総会において発表した。

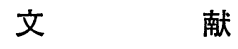
1) Kober, J.B. : J. Endocrinol., $8: 196$ (1952).
2) 神戸川明 : 日内分泌誌, $37: 807,(1961)$. 
3) Ittlich, G. : Hoppe-Seyler's Z. Physiol. Chem., $312: 1$ (1958).

4) Wotiz, H.H. and S.C.

Chattoraj : Anal. Chem., 36 : 1466 (1964).

Wiele : Steroids, $15: 333$ (1970).

7）牧野拓雄：日内分泌誌，49：629,（1973).
5) Mikhail, G., G.H. Wu, M. Ferin and R.L. V. 6) Wu, C.H. and L.E. Lundy : Steroids, $18: 91$ (1971). ogic methods in steroid determination, (1970), 87, Appleton-Gentury-Crofts.

9) Feldman, H. and D. Rodbard : Principles of competitive protein-binding assays, (1971), 158, J.B. Lippincott Company. 10) 牧野拓雄, 他 : 臨床病理, $21: 858$, (1973). 11) Neeman, M. and Y. Hashimoto : J. Am. Chem. Soc., 84 : 2972 (1962). 12) Hashimoto, Y. and M. Neeman : J. Biol. Chem., $238: 1273$ (1963). 13) Goebelsmann, U., K. Sjöberg, N. Wiqvist and E. Diczfalusy : Acta Endocrinol., $50: 261$ (1965). 14) Wilson, R., G. Eriksson and E. Diczfalusy: Acta Endocrinol., $46: 525$ (1964). 15) Ahmed, J. and A.E. Kellie : J. Ster. Biochem., $3: 31$ (1972). 16) Tikkanen, M.J. : J. Ster. Biochem., $4: 57$ (1973).

17）神戸川明：木と臨床, $19: 355$, (1971). 18) Gurpide, E., M.E. Giebenhain, L. Tseng and W.G. Kelly : Amer. J. Obstet. Gynec., $109: 897$ (1971).

19) Castanier, M., J. Grenier and R. Scholler : J. Ster. Biochem., $3: 305$ (1972). $\quad 20$ ) Hennam, J.F., W.P. Collins and I.F. Sommerville : Steroids, $21: 285$ (1973). 21) Kellie, A.E., V.K. Samuel, W.J. Riley and D.M. Robertson : J. Ster. Biochem., $3: 275$ (1972). 22) Tikkanen, M.J. and H. Adlercreutz: J. Ster. Biochem., $3: 807$ (1972). 23) Goebelsmann, U.,G. Eriksson, E. Diczfalusy, M. Levitz and G.P. Condon : Acta Endocrinol., 53 : 391 (1966).

24) Schindler, A.E. and W.L. Herrmann : Am. J. Obst. Gynec., 95 : 301 (1966).

25) Klopper, A. : Am. J. Obstet. Gynec., 112 : 459 (1972). 